Brit. J. industr. Med., 1952, 9, 264.

\title{
SICKNESS ABSENCE RECORDING IN INDUSTRY
}

\author{
BY \\ J. P. W. HUGHES \\ From the Medical Research Council Statistical Research Unit, the London School of Hygiene and Tropical Medicine
}

(RECEIVED FOR PUBLICATION JUNE 9, 1952)

Time lost in industry may be due to normal and extraordinary leave, certified and uncertified sickness, accidents, leave without permission, and lateness. Clearly the " unexpected" absence, that is leave due to sickness and accident, absence without permission and lateness, is the most upsetting to industry since normal and extraordinary leave are accepted, and, in the main, foreseen. Furthermore, time lost by a worker sometimes means additional time lost by the group in which he or she works.

Of the "unexpected" absences sickness is the greater part, and there is evidence that certified sickness is much less influenced by socio-economic factors and legislation than are other unexpected absences. In any industrial concern there will always be some sickness unrelated to the type of work, or to personal relationships, pay, promotion, bonuses, feelings of importance or lack of importance, and good or bad management. Where, however, there are adverse environmental and social factors of this kind there may be an increased sickness absence, although this is not necessarily so, but there is always a still greater increase in absences from other causes. For instance, Behrend (1951) found in 46 factories in 1948 that "there appears to be no close connection between the level of the other reasons absence rate and the certified sickness absence rate", and, similarly, that there was only a negligible difference between the sickness absence rate in the 10 factories with the highest "other reasons" rate and that in the 10 with the lowest rates for other reasons. ("Other reasons" includes authorized leave.)

New cases of sickness absence are more commonly recorded as starting on Mondays and less commonly on Fridays, with a gradation between the two. Clearly Monday shows a peak because illness may have started on the preceding Saturday or Sunday, but as Behrend points out, the average daily certified sickness rate should be the same on every day of the week, with the exception that most return to work on a Monday and least on a Friday. In a company employing 370 men studied for nine months she found the average weekly certified sickness absence rates to be $3.0 \%$ on Monday and $3.2 \%$ on Friday. The highest level was $3.3 \%$ on Wednesday. There was therefore little difference throughout the week. Similarly in the coal-mines Behrend showed that the sickness rate was lowest on Monday and highest on Saturday, in contrast to the voluntary absence rate which was highest on Monday and Saturday and lowest on Friday.

These findings, taken in conjunction with Behrend's other demonstration of a lack of correlation between certified sickness absence and "other reasons " absence, suggest that a separate study of sickness absence is worth while because in the main it is caused by true.morbidity in the working population. Until there are adequate statistics of this kind in all sections of industry, it is impossible to apply preventive measures for the benefit of the work people and of the firms employing them. Adequately reliable data may be obtained from the statutory medical certificate, and small concerns should find it to their advantage to record and analyse them. Raffle (1950) in a large working group showed that in sickness and accident of long duration $80 \%$ of the diagnoses given on general practitioners' medical certificates fell into the same broad groups (of 21 headings) as the diagnosis subsequently made by the medical officers of the industry.

Employers often want to know how the sickness experience of persons employed by them compares with a similar labour force in other factories. If their own rate is high then a detailed analysis may point a remedy and allow measures to prevent illhealth to be taken. The comparisons required, even if the necessary data were available, are not quite as simple as they may appear to be. Sickness absence may be influenced by light or heavy work ; for example, a person with a chronic disability may be able to do a light job but not a heavy one and 
the same will often apply to a temporary disability. It is influenced by age, an important factor in an ageing population, and it is influenced by sex. Spratling and Lloyd (1951) point out that " the normal amount of sickness absence for men in the late fifties is about two or three times as much as it is in the twenties or early thirties ", while that "of women is normally more than that of men and that of unmarried women more than that of unmarried men". Various socio-economic factors which enter into everyone's life will also exert some influence on the amount of sickness experienced, though far less, it seems, on certified sickness than on other unexpected absences. It will be influenced by medical selection applied at entry, and, artificially, by the length of time a person is kept on the books.

Thus, comparisons of sickness absence between factories or between industries must be made with discretion. Within the same factories, or group of factories, with comparable work, inter-departmental or occupational comparisons may be made much more readily and with profit. Such comparisons may reveal unsuspected levels of sickness absence from particular causes.

For such purposes the first and essential step is the development of a simple and uniform method of recording sickness. An investigation, made in 1950 , of the medical facilities of a large group of factories in London, each of which employed up to 500 persons, revealed that only one in six had the part-time services of a doctor and few had any nursing service. If this picture is true of industry as a whole the great majority of factories lack any means by which disease or accident would normally be recorded in such a way as to reveal any excessive number or unusual nature of such occurrences. It should also be remembered, as Table 1 shows, that British industry still consists largely of relatively small units.

Observation of the smaller units of under 50 work people should hardly call for any detailed form of sickness absence recording ; in the largest, 1,000 employees or more, usually some system has already become a necessity. The simple system of recording to which this present study is devoted is, therefore, intended to be applicable and a guide to factories from 50 to 1,000 strong. Table 1 shows, assuming that all the entries are autonomous units, that these number some 23,000 , or one in eight of employers, and that they employ within their factories some $4,000,000$ operatives or over half of the total labour force of factories.

While the system of recording set out below is most easily used in factories, the same principles
TABLE 1

SIZE OF FACTORIES AT DECEMBER, 1949

\begin{tabular}{|c|c|c|c|c|c|c|}
\hline $\begin{array}{l}\text { Size of Firm } \\
\text { (Nos. Em- } \\
\text { ployed) }\end{array}$ & $\begin{array}{c}\text { No. of } \\
\text { Factory } \\
\text { Units }\end{array}$ & $\%$ & $\begin{array}{c}\text { Cumu- } \\
\text { lative } \\
\%\end{array}$ & $\begin{array}{l}\text { No. of } \\
\text { Em- } \\
\text { ployees } \\
\text { (000's) }\end{array}$ & $\%$ & $\begin{array}{c}\text { Cumu- } \\
\text { lative } \\
\%\end{array}$ \\
\hline $\begin{array}{c}1-10 \\
11-24 \\
25-49 \\
50-99 \\
100-249 \\
200-499 \\
500-999 \\
1,000-1,999 \\
2,000 \text { and over }\end{array}$ & $\begin{array}{r}132,338^{*} \\
17,114 \\
14,171 \\
10,138 \\
8,134 \\
3,190 \\
1,439 \\
601 \\
342\end{array}$ & $\begin{array}{r}70.6 \\
9.1 \\
7.6 \\
5.4 \\
4.3 \\
1.7 \\
0.8 \\
0.3 \\
0.2\end{array}$ & $\begin{array}{r}79.7 \\
87.3 \\
92.7 \\
97.0 \\
98.7 \\
99.5 \\
99.8 \\
100.0\end{array}$ & $\begin{array}{r}537^{*} \\
289 \\
498 \\
710 \\
1,265 \\
1,103 \\
984 \\
822 \\
1,277\end{array}$ & $\begin{array}{r}7.2 \\
3.9 \\
6.7 \\
9.5 \\
16.9 \\
14.7 \\
13.1 \\
11.0 \\
17.0\end{array}$ & $\begin{array}{r}\overline{11 \cdot 1} \\
17 \cdot 8 \\
27 \cdot 3 . \\
44 \cdot 2 \\
58 \cdot 9 \\
72 \cdot 0 \\
83 \cdot 0 \\
100 \cdot 0\end{array}$ \\
\hline Total & 187,467 & $100 \cdot 0$ & - & 7,485 & $100 \cdot 0$ & - \\
\hline
\end{tabular}

Data obtained from the Ministry of Labour Gazette for June, 1950.

* Firms employing 10 employees or less are not now required to make returns. These figures were obtained from the Census of Production Statistics of 1935 quoted in the Ministry of Labour Gazette for April, 1948. At this time the number of factories employing 10 or less persons was $73 \%$ of the total number of factories, so that little error will be made by their use.

can be, and have been, successfully used in other sections of industry. They may, too, it is hoped, be of use to medical officers acting as consultants to any occupational group.

\section{Short and Long Absences}

It has been generally agreed that a division should be made between short absences and those of greater length. The division is usually made at four days, absences of under this time (one, two, or three days) being termed "short" and those of four days or more being termed "long" (Medical Research Council, 1944; Spratling and Lloyd, 1951). Though long absences are in many ways the more important, there is no doubt that short absences should also be fully recordod and studied, since they invariably form a large proportion of the total sickness absence (sometimes as much as one half) and have quite a different pattern of causes. Many will be unsupported by a medical certificate, and, as Spratling and Lloyd suggest, it may well be that "social, economic, and administrative factors exert a greater influence than the purely medical " on them. To ignore these relatively numerous terms of short sickness is, however, to lose information on much general, though minor, morbidity, and as part of these absences are certified it is arguable that short absence data are not appreciably less reliable than those of long.

To ensure comparability in the sickness absence rates of different concerns it is also necessary to place some upper limit on an absence. Otherwise, as already pointed out, the rates will be artificially swollen or shrunken by the length of time a sick person is kept on the books. The Medical Research Council and Spratling and Lloyd place this limit 
at six months (or 182 days) and suggest that sickness absence in excess of this should be analysed separately. This division has been adopted here, though it may be noted that in small firms the amount of data relating to absences of over six months is unlikely to be sufficient to repay analysis.

\section{Method of Recording Sickness}

The larger firm which possesses a personnel or medical department may use either of these services for its sickness absence recording. Of the two, the personnel department is generally the more suitable unless the medical officer is whole-time, for it is not unusual to find that there is lack of liaison in questions of absence in these departments where medical advice is not always available, consequently a medical officer may keep his own statistics of consultations while the personnel officer keeps records from observations of medical certificates.

In a small firm lacking a personnel officer a suitable department must be found within the existing framework without, if possible, increasing the sitaff. Fortunately the "pay point" is readily suitable for this. In the wages department it is necessary to have day-to-day information about employees solely for the purposes of calculating pay. If a worker is absent he is recorded as such and the recording of why the individual is away is merely a simple extension of existing services. Also the wages department know the numbers of persons currently employed and the hours which they work in every branch of the organization.

In concerns with sub-units which make returns to a central wages department sickness absence is best collected by the manager at the head of the sub-unit. The responsible person should include on the return not only the numbers of days absent by any worker but also the reason for absence, which, for sickness or accident, will include the diagnosis on the medical certificate. This record relates to both an individual and to a group and is permanent. The individual items are transferred to the employee's personal documents, the diagnosis being coded, i.e. allocated to a group of similar illnesses, by a clerk centrally unless the sub-unit undertakes to code. The form may be designed to fit the particular industry, but one used by the London Transport Executive has proved of great value, and is here reproduced, slightly modified, as Form A. (A small concern could, of course, record directly on to the individual's documents without using this form at all.)

FORM A

Week ended : 29th March, 1952

Concern : Acme Toy Co. Dept.: Mechanical Section: Assembly

Confidential

PERSONS ABSENT THROUGH SICKNESS OR ACCIDENT

Average No. Employed : 83

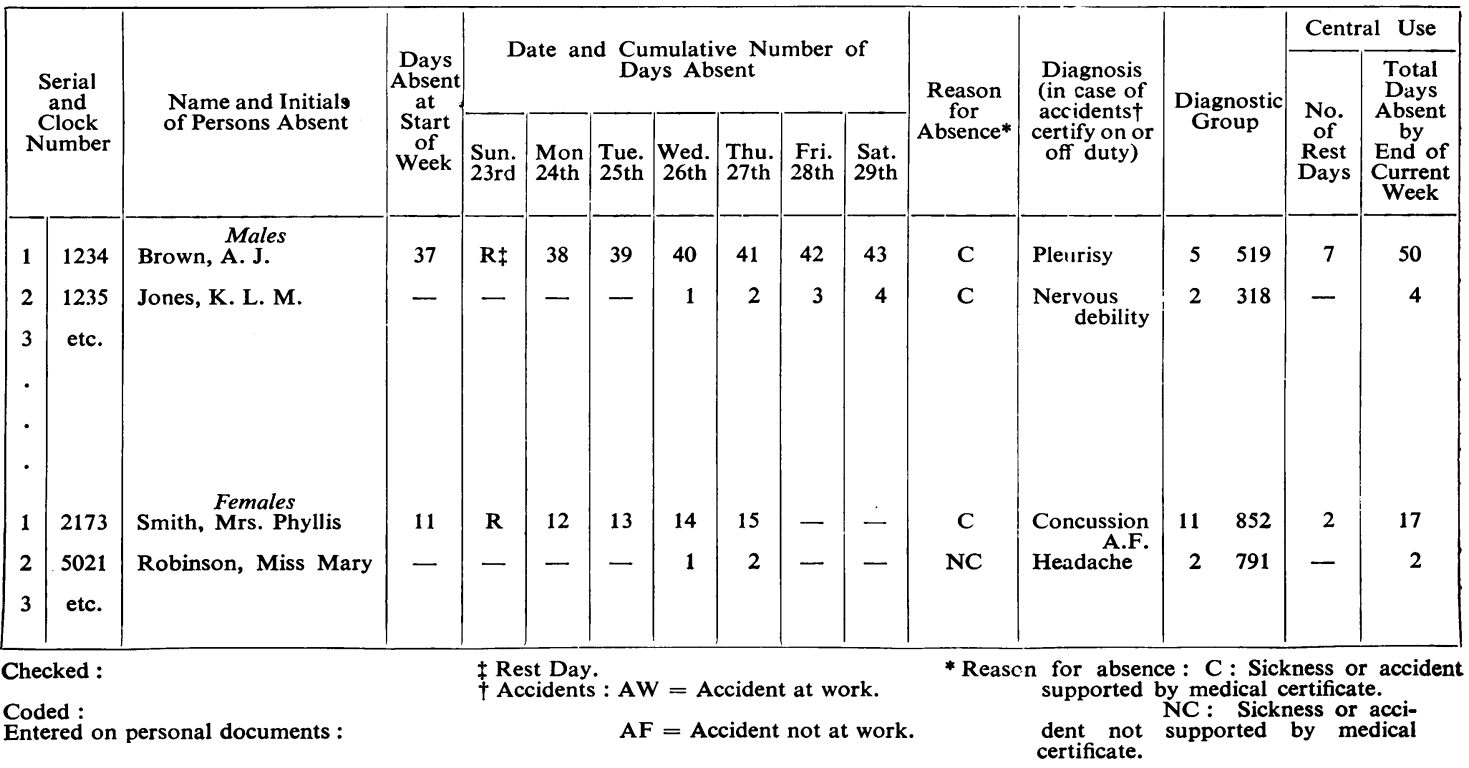

(Signed) A. Branch-Manager. 
The essential requirements for the form are : (1) a heading showing the name of the firm, department, unit, etc.; (2) the date(s) of the period under review; (3) space for entries for each individual absent (a) clock number, (b) name, initials and, for women, whether married or single (including widowed), (c) date of first and last day of absence and total number of days absent up to date, $(d)$ reason for absence ; (4) average number of persons employed during the period under review ; (5) the form should be marked " confidential" and have a space for signature by the person responsible for filling it in.

In practice the form shown is perforated at the left-hand margin and is made up in book-form. The second sheet is a carbon copy of the original and is retained by the sender. Rest days are marked with an $R$ and are not included in the cumulative totals of days absent from work, but, as they are important from the medical aspect, they are recorded by the clerk centrally in the penultimate right-hand column of the form, and added to the number of working days absent- to give the "total days absent" in the final column.

On the form Mr. A. J. Brown had, at the beginning of the week, already been absent continuously for 37 working days and he has a further week's absence, making a total of 43 working days which will be inserted at the beginning of next week's return, i.e. in the column headed "days absent at start of week". This relates to an unbroken period of absence. Any return to work for even a day brings that period of sickness to an end. During this illness Brown has been ill on seven Sundays, so that his "total days absent" is now 50 days. Unless Mr. K. L. M. Jones returns to work on Monday he will start with four days absence at the beginning of the following week and he will also have lost one rest day by this time.

Women's entries are kept separately. (This is always desirable to avoid confusion but it is not essential where numbers are very small.) Mrs. P. Smith suffered concussion due to an accident away from work, and is therefore recorded as an accident off duty. All except Miss Robinson produced medical certificates, and the diagnosis on the certificate or the employee's statement is entered in the appropriate column. Since the names, etc., of all who were away on the last working day of this week will be again inserted in the first three columns of the following week, unless they return on the Monday, those who have been longest away will automatically appear at the head of the form, and thus a daily tally is kept of the numbers of days any individual is absent. This is of great use when a member is drawing sick benefit over a limited period and for sick clubs and visiting schemes which need a day-to-day knowledge of each worker.

Saturday, when worked, is counted as a whole day (and, of course, if not worked as R). Where the working population is varying the average number employed is obtained by adding the numbers who should be present (this includes the absentees) on the Monday to those who should be present on the Saturday (or Friday in a five-day week) and dividing by 2 . Where the population is steady, the number who should be present at the beginning of the week is all that is necessary.

\section{The Individual Records}

Form $\mathrm{A}$ is the group record. For each worker it is desirable to have two records. One is the master or main record, the other the temporary or annual record.

The Master Record.-The master record is a card which will last the worker throughout his employment. The non-changing, or only rarely changing, information about the individual is entered on it. Two record cards may appear extravagant but they are in fact deliberately suggested in order, first to avoid the waste of paper which occurs where a single document is used for all recording and may have to be renewed several times a year, and secondly to save the clerk's time in constantly transferring the same information (date of birth, etc.) from card to card annually, or when the card is full. Since all industrial concerns need a master record of certain details of their work people, and as the amount will vary with the firm, no attempt has been made to design such a card, but the suggestions made here might be added, where suitable, to existing records or incorporated in subsequent printings.

The master card consists of three parts: (1) means of identification of the employee; (2) unchanging (or infrequently changing) information essential for employment purposes; (3) other information for permanent record.

Under (1) are recorded the name and initials (and marital status for women), year of birth, and clock number. Sex is usually differentiated by the colour of the cards. Under (2) are recorded the employee's address (with space for two changes), date of entry to the firm, details of previous jobs and qualifications for the present one, grading, present occupation, and department. Sufficient space is left for promotions and other changes in status or work. Further spaces are required for recording whether the employee is a young person or a 
disabled person. It is generally not practicable to record the rate of pay on this main card owing to frequent changes but a small firm may find it an advantage to do so. Under (3) are recorded, when known, important details of the individual's life, not necessarily confined to his industrial life; these will include any medical history and details of examinations made by a doctor for the firm. In this section, too, it is desirable to include the total annual amounts of sickness and accident absence which have occurred over the previous years.

A suggested design of this section is shown in Form B. Four main columns are required. The first records the calendar year, the second the numbers of days absent due to sickness and accident in that year, the third the number of absences in

Form B

(Medical Section of Master Record)

SICKNESS AND ACCIDENT OCCURRING IN FORMER YEARS

\begin{tabular}{|c|c|c|c|c|}
\hline \multirow{3}{*}{ Year } & \multicolumn{2}{|c|}{ No. of Days Absent } & \multicolumn{1}{|c|}{$\begin{array}{c}\text { No. of } \\
\text { Absences }\end{array}$} & $\begin{array}{c}\text { Accidents. } \\
\text { Detail } \\
\text { and } \\
\text { whether } \\
\text { AW or AF }\end{array}$ \\
\cline { 2 - 5 } & Working & Rest & Total & \\
\hline & & & & \\
\hline & & & & \\
\hline
\end{tabular}

the year, and the fourth gives brief details of the circumstances leading to, and nature of, each accident. Whether each was at work (AW) or not at work (AF) is also recorded. These summaries of sickness have proved of great value in large industrial concerns, e.g. the General Post Office, and are important in any concern when a medical officer undertakes to assess the health of an individual. The summaries from the current record are made at the beginning of each calendar year.

When employment ceases the main card passes to a wastage file, and, from this, labour turnover statistics can be compiled.

The Annual Record.-The annual record of the employee may, in the small firm, be filed with the main card and show only enough means of identification on it to link the two. It is, however, invariably simpler to compile statistics on sickness without reference to the main card. Thus the annual record, when not used in conjunction with the main record, requires : (1) means of identification (as on the main card) ; (2) year of birth ; (3) grade ; (4) department; (5) occupation. A suggested form is shown below (Form C).

Form $\mathrm{C}$ has been designed for easy alphabetical filing by name. As with the master card sex can be differentiated by colour, and the name should include initials for men and Christian name for women. The cards can be sorted by department

FORM C

\begin{tabular}{|c|c|c|c|c|c|c|c|}
\hline \multirow{2}{*}{\multicolumn{2}{|c|}{$\begin{array}{l}\text { Name of } \\
\text { concern : } \\
\text { Department : } \\
\text { Section : } \\
\text { Occupation : }\end{array}$}} & \multirow{2}{*}{\multicolumn{3}{|c|}{ 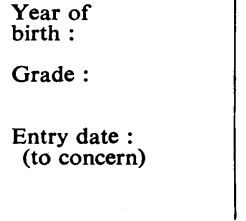 }} & \multirow{2}{*}{\multicolumn{3}{|c|}{$\begin{array}{l}\text { Name : } \\
\text { Marital status: } \\
\mathbf{M} / \mathbf{S} / \mathbf{W} \\
\text { Clock No. : }\end{array}$}} \\
\hline & & & & & & & \\
\hline \multicolumn{8}{|c|}{ Periods of Absence } \\
\hline \multirow{3}{*}{$\begin{array}{c}\text { Date } \\
\text { of } \\
\text { Onset }\end{array}$} & \multirow{3}{*}{\multicolumn{2}{|c|}{$\begin{array}{l}\text { Reason for Absence } \\
\text { (Code for Sickness } \\
\text { and Accident) }\end{array}$}} & \multirow{3}{*}{$\begin{array}{c}\text { C or } \\
\text { NC } \\
\text { and } \\
\text { AW } \\
\text { or AF }\end{array}$} & \multicolumn{4}{|c|}{ Number of Days Absent } \\
\hline & & & & \multirow{2}{*}{$\begin{array}{l}\text { Work- } \\
\text { ing. } \\
\text { Days }\end{array}$} & \multirow{2}{*}{$\begin{array}{l}\text { Rest } \\
\text { Days }\end{array}$} & \multicolumn{2}{|c|}{ Total Days } \\
\hline & & & & & & SA* $^{*}$ & LA $\dagger$ \\
\hline \multicolumn{8}{|l|}{115} \\
\hline \multicolumn{8}{|l|}{$1 / 5$} \\
\hline \multicolumn{8}{|l|}{115} \\
\hline \multicolumn{8}{|l|}{115} \\
\hline \multicolumn{8}{|l|}{$1-15$} \\
\hline & Ann & $\begin{array}{l}\text { (date) } \\
\text { tals at }\end{array}$ & $\begin{array}{l}\text { AW } \\
\mathbf{A F}\end{array}$ & & & & \\
\hline
\end{tabular}

and section, occupation, year of birth, grade and marital status (women), and can be used, if wished, for monthly or quarterly periods by ruling off at the end of these times and adding sub-totals. Particulars of pay may be given under "grade". Sufficient space is allowed for at least one change under each heading " department", " section", " occupation", and "grade". If an individual changes his occupation within the concern more frequently than this in the year a new card should be issued. The actual day of the week on which any absence started can be added in the "date of onset " column if required. (Behrend has shown this to be of importance when setting a target to reduce absenteeism. It is, however, of less importance in sickness absence and is more readily obtained from Form A.)

On receiving information of new absences from Form A, or from the clock cards in smaller concerns, the card $\mathrm{C}$ is marked in columns 1 and 2 (date of onset and reason for absence) and then kept in hand until the sickness incident is complete, or until the 182nd day, when the remaining information is recorded. This includes, in column 3 , recording whether the absence is certified or uncertified and, for accidents, whether AW or AF. The number of 
working and rest days absent are inserted in columns 4 and 5 respectively, and the total days lost are divided into short absences of under four days (SA) or long absences of four days or more (LA). On completion the card is returned to the file. Each separate period of absence is thus entered and at the end of the year totals are made of their numbers (column 1), the numbers of accidents at work and not at work (AW and AF entries in column 3), the number of working days lost, the number of rest days "lost", and the days lost due to short and long absences. This information is transferred to the main card, and the annual card, after statistical analysis, can be passed to a dead file.

\section{Coding of Diagnoses}

As medical certificates are frequently intended for perusal by lay persons they are couched in general or simple terms. Occasionally, sometimes deli- berately, they are illegible, blank or obscure, but where a firm has the advice of a medical officer a high degree of accuracy in interpretation can be achieved ; since, however, the purpose here is to enable lay persons with no special knowledge to code the great majority of diagnoses, it is necessary to aim at a short list which is exhaustive for this particular purpose. Diagnoses which do not conform to the list given in the Appendix should, therefore, be placed in the miscellaneous group. This list includes diagnoses experienced by industrial and other concerns in London, the Home Counties, and the Midlands. There are, however, local variations in fashions in terms of diagnosis; and in time any list becomes out of date. In addition, therefore, to the experience of the areas already mentioned, the present list was based on, and includes, the majority of diagnoses from the corresponding list given in Appendix $B$ of the Industrial Health Research Board Report No. 85 (Med. Res. Coun., 1944), which was itself prepared from country-wide experience. Local additions, or sub-divisions, may be necessary, particularly where there are hazards not experienced by the majority ; for example, silicosis would be taken as a special sub-group of Group 5 (see Appendix) in those working groups exposed to such a hazard, while medical advice might well be sought if in any analysis more than about $10 \%$ of the diagnoses fall into the miscellaneous group.

The classification used is that of the International Statistical Classification of Diseases, Injuries, and Causes of Death (1948) with certain re-grouping of the components to provide essentially for minor morbidity in the industrial population. Any one using the full international code can readily re- group his data into the dozen categories suggested in the Appendix, and similarly anyone using this list could put the original coded data almost wholly into the international code.

The international code has 17 main sections to cover all modes of sickness and accident. Some of these are not applicable to an industrial population, e.g. diseases of infancy, and others, such as senility and neoplasms, are very seldom needed. For all normal purposes, therefore, it is suggested that 12 main groups will suffice. At the same time for each cause of absence the three-digit international code number is recorded as well, for it is from this that comparisons between concerns not using the present suggested system could be made, provided always that the other concerns have based their coding similarly on the international classification. The code figures placed against each diagnosis therefore are a single or two-digit group number followed by the three-digit international list number for that diagnosis; for example, "pneumonia" falls in group 5 of the classification proposed here and its number in the international list is 493. Since some diagnoses must fall into the miscellaneous group, they cannot, from the following Appendix, be coded according to the international code ; it is important, therefore, that the diagnosis in words be recorded on the individual's documents, particularly when no code number has been allotted to it.

In the full international list accidents (Section XVII) are recorded both by the external circumstances giving rise to the injury, the $\mathrm{E}$ code, and by the nature of the injury, the $\mathrm{N}$ code ; the sub-group numbers are in each case 800-999. Only the $N$ code is used in the present coding, and, since the numbers 800-999 thus refer only to the nature of the injury, they do not require the prefix $\mathrm{N}$.

The international classification of disease is, in the main, anatomically determined, and this anatomical grouping has been retained and expanded in constructing the groups suggested for the present study. Thus certain sub-groups from Section I of the international classification (infective and parasitic diseases) have been removed from this group and placed under the anatomical site principally affected : for example, pulmonary tuberculosis, 002 , has been allocated to the diseases of the lower respiratory system (present Group 5). Dysentery, similarly, has been added to the intestinal group (present Group 7). Most of the remaining diagnoses in this section have not been listed at all in the Appendix as their frequency in industry in this country is low. Similarly Section II of the international code (neoplasms) has not been classified 
here, and certain conditions from Section III (allergic, endocrine, metabolic, and nutritional diseases) have been placed against their normal anatomical sites. For example, hay fever, 240, has been allotted to the upper respiratory system (Group 4) and asthma to the lower respiratory system (Group 5).

Sections IV and VII of the international classification (diseases of the blood and blood-forming organs and diseases of the circulatory system) have been combined to form Group I in the classification here proposed for use in industry. Sections V and VI become Groups 2 and 3-with identical titleswhile Section VIII (diseases of the respiratory system) has been here sub-divided into Groups 4 and 5 representing upper and lower respiratory disease respectively. Section IX (diseases of the digestive system) has similarly been sub-divided at the level of the duodenum. The upper part of the intestinal canal includes disorders of the mouth, (oesophagus), stomach, and duodenum in the present Group 6, and lower alimentary disease together with diseases of the abdominal organs in Group 7. Sections X and XI dealing with genitourinary disease have been combined with pregnancy, childbirth, and the puerperium to form the present Group 8. Section XII (diseases of the skin and cellular tissue) becomes, with some additions relating to the lymphatic glands, the suggested Group 9, and Section XIII (diseases of the bones and organs of movement) forms the present Group 10. Accidents (Section XVII) are classified under Group 11 as $A W$ or AF, it being unimportant from the point of view of medical classification whether these occurred at work or not, although, of course, the differentiation is of the utmost importance to industry. Group 12 is the miscellaneous group which covers all diagnoses not on the list, and blank and illegible certificates. In this group the three-digits 000 are coded after the group number 12.

Section XVI of the international classification contains "symptoms and ill-defined conditions", and; since the medical certificate in industry may not infrequently record only such terms, e.g., vertigo, oedema, pleurodynia, they have been related to the appropriate anatomical group. Certain conditions which are quite commonly recorded on certificates are difficult to classify; for example, phlebitis, unqualified, cannot strictly be coded, or, more often, having been coded, they are difficult to place appropriately in a group. Such terms as " black-out", " chill", " oedema ", and " headache" are not easily placed. Groups, however, have been found for them on the grounds that their relegation to the miscellaneous group would be a greater loss than would arise through a disagreement in grouping of a few individual diagnoses.

Any such classification is an exercise in eclectics, but the anatomical basis of disease is less often in doubt than is any alternative system, both from its nature, and, more important in the present study, from its coding by lay persons.

Small firms could shorten the grouping still further by combining Groups 4 and 5 into a single group of respiratory diseases and 6 and 7 into another of digestive diseases. Group 8 can be relegated to the miscellaneous group as it is always small and unnecessary when males only are employed. This would make a total of eight defined groups and one miscellaneous, and should suffice for valuable medical statistics to be gathered; further reduction is inadvisable.

\section{Statistical Analysis of the Data Recorded}

The foregoing methods of recording have supplied the following data : (1) individual information on each person who has been absent, namely the number of days lost by short and long absences, the diagnosis of the cause of sickness and its diagnostic group and, in the case of an accident, whether it took place at or not at work ; (2) the numbers of men and women employed in the group under study, with sub-divisions, if -required, by married and single women, certain age groups, etc.; (3) the number of days worked by the group; (4) the total number of days lost by the group through sickness and accident ; (5) the number of persons who have been absent in relation to each diagnosed cause of sickness.

When using such data certain broad principles may be postulated as a guide. As a general rule he who initiates a scheme of recording should supervise the analysis, and the rates used should be easy to calculate and be easily appreciated by those who take action on them. It is, for instance, generally easier to interpret figures as percentages, but care must be taken that the numbers in the group are not so small as to make the percentage figure fallacious ; for example, one absent in a group of five would give a $20 \%$ absence rate but this figure is obviously not of the same significance as, say, 12 persons away in a group of 60 . In another sense percentages can be misleading when, for example, the percentage of all absences falling in each diagnostic group is calculated. Since each kind of sickness is being expressed as a proportion of the total it follows that the total must be $100 \%$. An epidemic of influenza might raise the percentage in Groups 4 and 5 from, say, $5 \%$ to $30 \%$, and must then corres- 
pondingly lower the percentage in some other groups, even though the absolute numbers of persons absent from these other causes is not lower.

It is clear that very small groups of under 20 or 30 persons should be compared only with caution or over a long period of time ; preferably groups of 50 or more should be considered, and it may sometimes be necessary to group departments in order to achieve this. Finally as a general rule absences of men and women should not be considered together except to obtain an overall figure for a concern which may be desirable economically. These are merely commonsense points but they may serve to emphasize the need of care in the interpretation of results.

The essence of the statistical analysis is to find the numbers absent, and the time lost in relation to the numbers in, and the total time worked by, a particular department, section, etc. A concern, for instance, may wish to compare the average amount of time lost by short term sickness and accident as against long term sickness and accident. At the end of some specified period (usually month, quarter, or year) the number of days lost by short term absence and long term absence are separately aggregated. The cards are then sorted into the two sexes and four calculations are now required. The formula for the first may be expressed as :

Total no. of days lost by men due to short absence in some specified period of time

Average no. of men employed in the specified period of time

The remaining three calculations are made for long absence occurring amongst men, and long and short absence occurring amongst women in exactly the same way.

It may be desirable similarly to break down the figures arising from the example given below into the number of days lost by short and long term absence. If one of the groups shows more days lost than the others a more detailed investigation may be necessary into the types of sickness and accident suffered. (It should be remembered that in a small group one long-term illness may throw the figures out and if this occurs it should be noted.)

The following four calculations are thought to be the most useful for industrial management. First the average number of days lost per person through sickness and accident during some specified periodmonth, quarter, or year. This may be the total number of days lost or the number of working days lost. It may be sub-divided into younger and older men and younger and older women, into departments, etc. A concern, for example, may wish to compare the average amount of working time lost by sickness and accident in younger as against older employees. Some point of age may be chosen (say, 45 years) and the cards first sorted by sex and then by age. The first of the four calculations becomes :

No. of working (or total) days lost by men under 45 years of age in the specified period

Average no. of men under 45 years employed in the specified period

Following this the average number of working (or total) days lost by older men and older and younger women are now calculated.

Second, the loss of working time due to sickness and accident may be expressed as a proportion of the total time worked. The formula is :

$$
\frac{\text { Total no. of working days lost }}{\text { Total no. of possible working days }} \times 100
$$

The total number of possible working days is readily calculated by multiplying the number of persons in the group under study by the number of working days in the specified period. The total number of days lost is, of course, the aggregate of the individual losses (most easily obtained from Form A).

Third the percentage is calculated of persons who have been absent during a specified period. The formula is :

$$
\frac{\text { Total no. of workers absent one or more times }}{\text { Average no. of workers employed }} \times 100
$$

Fourth the average number of absences per worker during a specified period is required. The formula is :

$$
\frac{\text { Total no. of absences }}{\text { Average no. of workers employed }}
$$

It should be noted that in concerns where there are a number of grades comparisons between them may need to be made with considerable care if their conditions of employment vary. For instance, persons who have a month's annual holiday are at risk for 14 days less than those who have only a fortnight, those who work on Saturdays (counted as a whole day) are at risk for up to 52 extra days in the year. Strictly, of course, all these persons are at risk for the same period in regard to illness, but they are not necessarily recorded as being ill at week-ends or during their holidays.

In considering annual returns there is an advantage in studying the year from April 1 to March 31 rather than the calendar year. This is because epidemics occur about the turn of the calendar year, particularly of influenza and upper respiratory disease, the greatest causes of lost time in industry at this period. If an epidemic of influenza occurs late in the season, say January and February, 1952, and early in the following season, say November, December, 1952, then the incidence of sickness will 
be much greater when calculated on a calendar year basis in 1952 than in either 1951 or 1953.

\section{The Presentation of Results}

Complete information is now available and it remains only to suggest suitable means of presentation of the results.

Classification of Causes of Sickness and Accident.Form $D$ is designed to show, after the name of the department concerned and the dates of the period under review, the absolute number of cases starting in the period under review, the number of cases continuing into that period, and the number of days lost, for men and women separately and for each diagnostic group. The last column shows the percentage of the total loss $(100 \%)$ due to each diagnostic group, calculated as follows : $\frac{\text { No. of days lost by each sex in diagnostic Group X }}{\text { Total no. of days lost by each sex in all diagnostic groups }} \times 100$

Quarterly and annual returns are made by aggregating monthly totals and re-calculating the percentages.

Analysis of Sickness and Accident by Sex and Department.-A suitable form for setting out the analysis of absence by sex and department is given in Form E.

Column 1 shows the sex and column 2 each department by name or code. The average number employed (column 3 ) is obtained by averaging the weekly aggregates, and the total number of working days (column 4) is the number of persons in the department multiplied by the number of working days in the period under review. Column 5 shows the actual number of persons who were absent one or more times, and column 6 the total number of days they lost. Column 7 gives the average number of days lost per person employed, i.e. column 6 divided by column 3 .
FORM D

CLASSIFICATION OF CAUSES OF SICKNESS AND ACCIDENTS

Dept............. $\quad \ldots \ldots \ldots \ldots \ldots 195 \ldots$

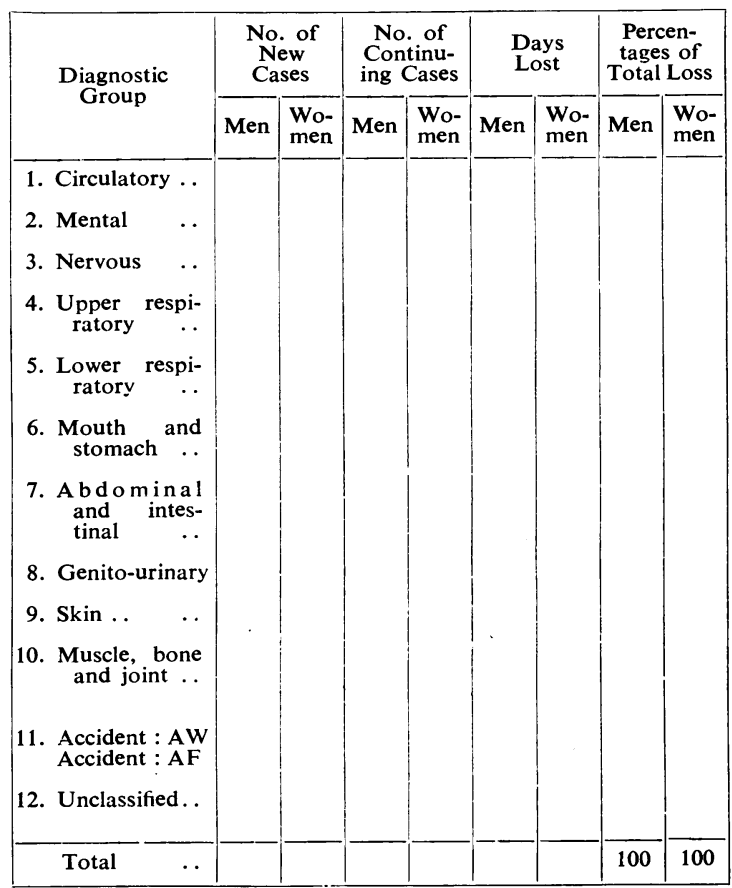

New cases are those beginning between midnight on the last day of the previous period and midnight on the last day of the current period. Continuing cases are those beginning before the current period.

Column 8 gives the percentage loss of time and is obtained by dividing column 6 (days lost) by column 4 (no. of working days) and multiplying by 100. Finally column 9 shows the percentage of persons absent, i.e., column 5 divided by column 3 then multiplied by 100 .

\section{FORM E}

Name of Concern...................

ANALYSIS OF SICKNESS AND ACCIDENT ABSENCE BY SEX AND DEPARTMENT

\begin{tabular}{|c|c|c|c|c|c|c|c|c|}
\hline $\begin{array}{l}\text { Sex } \\
\text { (1) }\end{array}$ & $\begin{array}{c}\text { Department } \\
\text { (2) }\end{array}$ & $\begin{array}{c}\text { Average No. } \\
\text { Employed } \\
\text { (3) }\end{array}$ & $\begin{array}{c}\text { Total No. } \\
\text { of Working } \\
\text { Days } \\
\text { (4) }\end{array}$ & $\begin{array}{c}\text { No. of } \\
\text { Persons } \\
\text { Absent } \\
\quad(5)\end{array}$ & $\begin{array}{c}\begin{array}{c}\text { No. of } \\
\text { Days Lost }\end{array} \\
\text { (6) }\end{array}$ & $\begin{array}{c}\text { Average No. } \\
\text { of Days Lost } \\
\text { per Person } \\
\text { Employed } \\
\text { (7) }\end{array}$ & $\begin{array}{c}\text { Percentage } \\
\text { Loss of } \\
\text { Time } \\
(8)^{*}\end{array}$ & $\begin{array}{c}\text { Percentage } \\
\text { of Persons } \\
\text { Absent } \\
\text { (9) }\end{array}$ \\
\hline Male & & & & & & & & \\
\hline Total & & & & & & & & \\
\hline Female. . & & & & & & & & \\
\hline Total & & & & & & & & \\
\hline $\begin{array}{l}\text { Total } \\
\text { M. }+ \text { F. }\end{array}$ & & & & & & & & \\
\hline
\end{tabular}

* State whether a five- or six-day week. 
This form gives on a single page a useful summary of the health of a concern over a specified period, and should reveal where further detailed analysis, e.g. by age and diagnostic cause, is called for and where preventive action against ill health or accident needs to be taken.

I am greatly indebted to Prof. Bradford Hill, C.B.E., for advice and constant help throughout, and to the members of the Medical Research Council's Occupational Health Committee individually for advice and helpful criticism. Thanks are also due to Mr. F. J. Lloyd, Dr. L. G. Norman, and Dr. P. A. B. Raffle, of the
London Transport Executive, on whose work much of this study depends, and to the concerns listed in I.H.R.B. Report No. 85 for putting their valuable experiences at my disposal.

\section{REFERENCES}

Behrend, H. (1951). Absence under Full Employment. Monograph A3, Faculty of Commerce and Social Science, University of Birmingham.

Medical Research Council (1944). Rep. industr. Hlth Res. Board, Lond., No. 85.

Ministry of Labour (1948). Gazette, 56, 126.

(1950). Ibid., 58, 189.

Raffle, P. A. B. (1950). Personal communication.

Spratling, F. H., and Lloyd, F. J. (1951). J. Inst. Actu., 77, 196.

A P P E N D I X

\begin{tabular}{|c|c|c|c|}
\hline $\begin{array}{l}\text { Group } \\
\text { No. }\end{array}$ & Name of Group & \multicolumn{2}{|c|}{$\begin{array}{l}\text { International } \\
\text { Classification }\end{array}$} \\
\hline 1 & $\begin{array}{l}\text { Diseases of the circulatory system, } \\
\text { blood, and blood-forming } \\
\text { organs }\end{array}$ & $\begin{array}{l}\text { IV } \\
\text { VII } \\
\text { XVI }\end{array}$ & $\begin{array}{l}293 \\
410 \\
420 \\
422 \\
433-4 \\
443-4 \\
453 \\
460-1 \\
463 \\
466 \\
782\end{array}$ \\
\hline 2 & $\begin{array}{l}\text { Mental, psychoneurotic, and } \\
\text { personality disorders }\end{array}$ & $\begin{array}{l}\text { V } \\
\text { XVI }\end{array}$ & $\begin{array}{l}310 \\
315-6 \\
318 \\
790-1\end{array}$ \\
\hline 3 & $\begin{array}{l}\text { Diseases of the nervous system } \\
\text { and sense organs }\end{array}$ & $\stackrel{I}{\text { VI }}$ & $\begin{array}{l}088 \\
353-4 \\
360 \\
363 \\
366 \\
370-3 \\
381 \\
391 \\
394 \\
780\end{array}$ \\
\hline 4 & Upper respiratory disease & $\begin{array}{l}\text { I } \\
\text { III } \\
\text { VIII }\end{array}$ & $\begin{array}{l}051 \\
070 \\
240 \\
470-4 \\
481-2 \\
511-2 \\
514-5\end{array}$ \\
\hline 5 & Lower respiratory disease & $\begin{array}{l}\text { III } \\
\text { VIII } \\
\text { XVI }\end{array}$ & $\begin{array}{l}002 \\
241 \\
480 \\
490-3 \\
501 \\
518-9 \\
522 \\
527 \\
783\end{array}$ \\
\hline 6 & $\begin{array}{l}\text { Diseases of mouth, stomach, and } \\
\text { duodenum (upper alimentary } \\
\text { tract) }\end{array}$ & 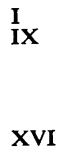 & $\begin{array}{l}048-9 \\
530-4 \\
536 \\
538 \\
540-1 \\
543-4 \\
784\end{array}$ \\
\hline 7 & $\begin{array}{l}\text { Diseases of abdominal organs and } \\
\text { intestinal tract }\end{array}$ & $\begin{array}{l}\text { IX } \\
\text { XVI }\end{array}$ & $\begin{array}{l}092 \\
551 \\
560 \\
571-2 \\
574 \\
584-5 \\
785\end{array}$ \\
\hline
\end{tabular}

\begin{tabular}{|c|c|c|c|}
\hline $\begin{array}{l}\text { Group } \\
\text { No. }\end{array}$ & Name of Group & \multicolumn{2}{|c|}{$\begin{array}{l}\text { International } \\
\text { Classification }\end{array}$} \\
\hline 8 & $\begin{array}{l}\text { Diseases of genito-urinary system, } \\
\text { disorders of pregnancy, child- } \\
\text { birth, and puerperium }\end{array}$ & $\begin{array}{l}\text { X } \\
\underset{\text { XVI }}{\text { XI }}\end{array}$ & $\begin{array}{l}593 \\
600 \\
605 \\
613-4 \\
630 \\
634 \\
637 \\
649 \\
789\end{array}$ \\
\hline 9 & $\begin{array}{l}\text { Diseases of skin, cellular tissue, } \\
\text { and lymphatic glands }\end{array}$ & $\begin{array}{l}\text { I } \\
\text { III } \\
\text { XII }\end{array}$ & $\begin{array}{l}052 \\
131 \\
243 \\
690-6 \\
700-3 \\
705-6 \\
708 \\
712 \\
714-5 \\
786 \\
788\end{array}$ \\
\hline 10 & $\begin{array}{l}\text { Diseases of bones, joints, and } \\
\text { organs of movement }\end{array}$ & $\begin{array}{l}\text { III } \\
\text { XIII }\end{array}$ & $\begin{array}{l}288 \\
722-3 \\
725-7 \\
734 \\
738 \\
740-2 \\
746-7 \\
787\end{array}$ \\
\hline 11 & $\begin{array}{l}\text { AW. Accidents } \\
\text { AF. (In the list of diagnoses the } \\
\text { prefix is not given and is not } \\
\text { coded) }\end{array}$ & NXVII & $\begin{array}{l}\text { N803 } \\
\text { N807 } \\
\text { N817 } \\
\text { N824-6 } \\
\text { N829 } \\
\text { N839 } \\
\text { N842 } \\
\text { N845 } \\
\text { N850-2 } \\
\text { N869 } \\
\text { N879 } \\
\text { N883-4 } \\
\text { N985 } \\
\text { N914-5 } \\
\text { N917-8 } \\
\text { N928-30 } \\
\text { N941 } \\
\text { N944 } \\
\text { N949 }\end{array}$ \\
\hline 12 & Miscellaneous & $\begin{array}{l}\text { All sect } \\
\text { and } \\
\text { of se } \\
\text { XIII, } \\
\text { XVII } \\
\text { above }\end{array}$ & $\begin{array}{l}\text { s II, XIV, } \\
\text { and parts } \\
\text { 2ns I, III- } \\
\text { KVI, and } \\
\text { t included }\end{array}$ \\
\hline
\end{tabular}




\section{CODING OF COMMON ILLNESSES}

\begin{tabular}{|c|c|c|}
\hline \multicolumn{3}{|l|}{$\mathbf{A}$} \\
\hline Abscess & 9 & 692 \\
\hline Abscess of ear. & $\ldots$ & 391 \\
\hline Adenitis, acute & . & 694 \\
\hline Alveolar abscess & $\ldots$ & 531 \\
\hline Anaemia $\quad \ldots$ & $\ldots$ & 293 \\
\hline Anal fissure, fistula & .. & 574 \\
\hline Angina pectoris & . & 420 \\
\hline Anxiety state .. & $\ldots$ & 310 \\
\hline Appendicitis $\ldots$ & $\ldots$ & 551 \\
\hline Arrythmia, cardiac & $\ldots 1$ & 433 \\
\hline Arthritis $\quad \ldots$ & .. 10 & 725 \\
\hline Asthenia & .. 2 & 790 \\
\hline Asthma $\quad \ldots$ & $\ldots$ & 241 \\
\hline Athlete's foot .. & .. 9 & 131 \\
\hline
\end{tabular}

\section{B}

$\begin{array}{lllll}\text { Backache } & \ldots & \ldots & 10 & \mathbf{7 8 7}\end{array}$ $\begin{array}{llll} & & 3 & \mathbf{3 6 0} \\ & & 6 & \mathbf{5 4 4}\end{array}$ $\begin{array}{lllll}\text { Blackout } & \ldots & \ldots & \mathbf{5 4 4} & \mathbf{7 8 2} \\ \end{array}$

Bladder, diseases of $\ldots 8 \quad 805$

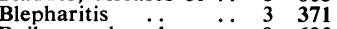

Boil or carbuncle $\quad \ldots 9969$

$\begin{array}{llll}\text { Bronchial asthma } & \ldots & 5 & \mathbf{2 4 1} \\ \text { Bronchial catarrh } & \ldots & \mathbf{5} & \mathbf{5 0 1}\end{array}$

$\begin{array}{lllll}\text { Bronchitis } & \ldots & \ldots & 5 & 501\end{array}$

Bronchopneumonia .. $54 \quad 591$

Bruise, see Contusion

Buccal sepsis .. $\quad \ldots \quad 6538$

Bunion $\therefore$. $\quad$. $10 \quad \mathbf{7 4 0}$

.. 11941 hand, wrist $\quad . \quad 11944$

$\begin{array}{ccccc}\text { other } & \ldots & \ldots & 11 & 949 \\ \text { Bursitis. . } & \ldots & . & 10 & 741\end{array}$

\section{C}

Carbuncle or boil .. 9690 Cardiac debility $\quad 2 \quad 690$ $\begin{array}{llll}\text { Cardiac debility } & \text {. } & 2 & \mathbf{3 1 5} \\ \text { Caries, dental .. } & \text {.. } & 6 & \mathbf{5 3 0}\end{array}$ Catarrhal cold, fever.. $4 \quad 4 \quad 470$ Catarrhal jaundice .. 7092 $\begin{array}{lllll}\text { Cellulitis } & \ldots & \ldots & \mathbf{9} & \mathbf{6 9 2} \\ \text { Cephalgia } & \ldots & \ldots & 2 & \mathbf{7 9 1}\end{array}$ $\begin{array}{lllll}\text { Cervicitis } & \ldots & \ldots & 8 & \mathbf{6 3 0}\end{array}$ Cheiropompholyx $\quad \ldots 99701$ $\begin{array}{lllll}\text { Chilblains } & \ldots & \ldots & 1 & \mathbf{4 5 3} \\ \text { Chill } & & & & \end{array}$ \begin{tabular}{lllll} 
Cholangitis & $\ldots$ & $\ldots$ & $\mathbf{7}$ & $\mathbf{5 8 5}$ \\
\hline
\end{tabular} $\begin{array}{lllll}\text { Cholecystitis } & \ldots & \ldots & 7 & \mathbf{5 8 5}\end{array}$

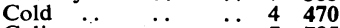

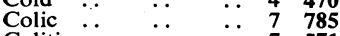
$\begin{array}{lllll}\text { Colitis } & \ldots & \ldots & 7 & 571\end{array}$ $\begin{array}{llrr}\text { Concussion } & \ldots & \mathbf{1 1} & \mathbf{8 5 2} \\ \text { Congestion of lungs } & \ldots & 5 & \mathbf{5 2 2}\end{array}$ $\begin{array}{llll}\text { Congestion of lungs } \ldots & 5 & \mathbf{5 2 2} \\ \text { Conjunctivitis } & \mathbf{3} & \mathbf{3 7 0}\end{array}$ $\begin{array}{llrl}\text { Conjunctivitis } & 3 & \mathbf{3 7 0} \\ \text { Contusion, foot, toes.. } & 11 & \mathbf{9 2 8}\end{array}$ $\begin{array}{llll}\text { scalp } & \ldots & 11 & \mathbf{8 5 1} \\ \text { other } & & 11 & \mathbf{9 2 9}\end{array}$

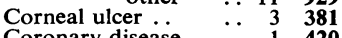

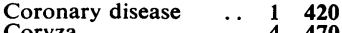
$\begin{array}{lllll}\text { Coryza } & \ldots & \ldots & \mathbf{4} & \mathbf{4 7 0} \\ \text { Cough .. } & \ldots & \ldots & 5 & \mathbf{7 8 3}\end{array}$

Cut, see Laceration $\cdots$ $\begin{array}{llll}\text { Cyst, sebaceous } & \ldots & 9 & \mathbf{7 1 4}\end{array}$ $\begin{array}{lllll}\text { Cystitis. . } & \ldots & \ldots & 8 & \mathbf{6 0 5}\end{array}$

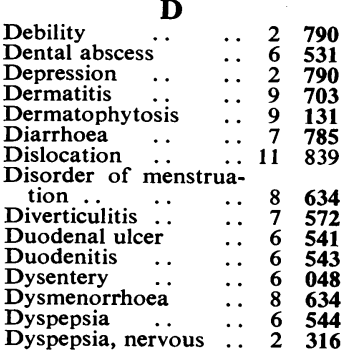
\begin{tabular}{lllll|} 
Earache & $\ldots$ & $\ldots$ & 3 & 394 \\
Eczema & $\ldots$ & $\ldots$ & 9 & 701
\end{tabular}
Emesis . Empyema $\ldots \quad \ldots \quad 5518$ $\begin{array}{llll}\text { Endocervicitis } & \ldots & \mathbf{8} & \mathbf{6 3 0} \\ & & \end{array}$ \begin{tabular}{llll} 
Enlarged glands & $\cdots$ & $\mathbf{1}$ & $\mathbf{7 8 2}$ \\
\hline
\end{tabular} Epidermophytosis $\quad \ldots \quad 96131$ $\begin{array}{lllll}\text { Epididymitis } & \ldots & \ldots & 8 & \mathbf{6 1 4}\end{array}$ $\begin{array}{lllll}\text { Epilepsy } & \text {. } & \text {. } & 3 & \mathbf{3 5 3} \\ & & \end{array}$ $\begin{array}{lllll}\text { Epistaxis } & \ldots & \ldots & 5 & \mathbf{7 8 3}\end{array}$ $\begin{array}{lllll}\text { Erysipelas } & \ldots & \ldots & 9 & \mathbf{0 5 2}\end{array}$

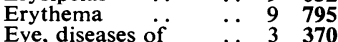

\section{F}

Facial paralysis Fainting attack $\quad \cdots \quad 3 \quad 360$ Fatigue..

Fibrositis

Flat feet

Fluid of knee .. $\quad \ldots 10 \quad 742$ Food poisoning 6049 Foreign body in eye $\cdots 111930$ Fracture ankle

$\begin{array}{llll} & \ldots & 11 & 824 \\ \text { foot } & \ldots & 11 & \mathbf{8 2 5} \\ \text { hand } & \ldots & 11 & \mathbf{8 1 7} \\ \text { ribs } & \ldots & 11 & \mathbf{8 0 7} \\ \text { skull.. } & \ldots & 11 & \mathbf{8 0 3} \\ \text { toes . } & \ldots & 11 & \mathbf{8 2 6} \\ \text { other } & \ldots & 11 & \mathbf{8 2 9} \\ \text { Furunculosis .. } & \ldots & 9 & \mathbf{6 9 0}\end{array}$

\section{G}

Gall stones _.. $\quad 7 \quad 7 \quad 584$ Gastric condition Gastric influenza

Gastric ulcer .

Gastritis

Gastro-enteritis

Giddiness

Glands, swollen

Glossitis

$\begin{array}{llll}\ldots & \ldots & 1 & \mathbf{7 8 2} \\ \cdots & \ldots & 6 & \mathbf{5 3 8}\end{array}$

Graze, see Injury, super-

ficial

Grippe . . . $\quad \ldots .4 \quad 481$

Gums, inflammation of $6 \mathbf{5 3 2}$

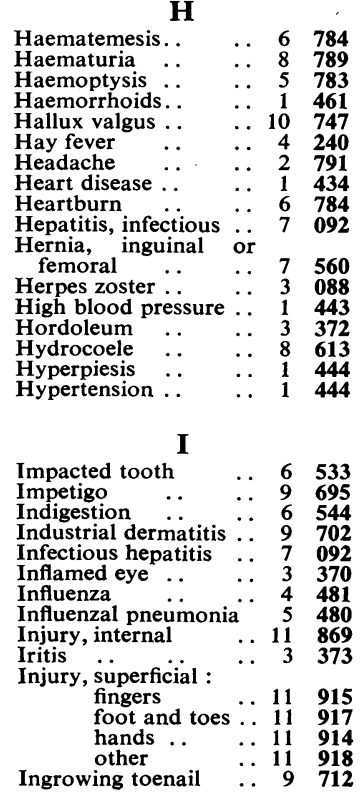
$\begin{array}{lllll}\text { Emphysema } & \ldots & \ldots & \mathbf{6} & \mathbf{7 8 4} \\ & & & & \\ & & & 527\end{array}$
Internal derangement

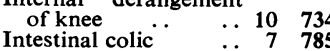

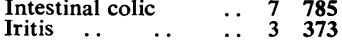

-

Jaundice

$\mathbf{J}$

$\mathbf{K}$

$\begin{array}{llll}\text { Kidney infection } & \ldots & \mathbf{8} & \mathbf{6 0 0} \\ \text { Kidney trouble } & & \mathbf{8} & \mathbf{5 9 3}\end{array}$ $\begin{array}{llll}\text { Knee cartilage. . } & \ldots & 10 & \mathbf{7 3 4}\end{array}$

\section{$\mathbf{L}$}

Laceration, face, neck,

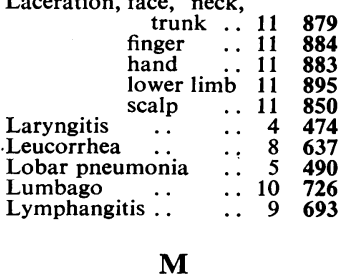

$\begin{array}{lllll}\text { Menorrhagia } . . . & \ldots & 8 & 634\end{array}$

$\begin{array}{llll}\text { Menstrual disorder } & \ldots & 8 & \mathbf{6 3 4} \\ \text { Migraine } & \ldots & 3 & \mathbf{3 5 4} \\ & & \end{array}$

$\begin{array}{lllll}\text { Migraine } & \ldots & \ldots & 3 & 354 \\ \text { Mitral stenosis } & \ldots & 1 & \mathbf{4 1 0}\end{array}$

Mouth, diseases of ... 6

Muscular rheumatism $10 \quad \mathbf{7 2 6}$

$\begin{array}{lllll}\text { Myalgia } & \ldots & . & 10 & \mathbf{7 2 6} \\ \text { Myocarditis } & \ldots & & 1 & \mathbf{4 2 2}\end{array}$

$\begin{array}{lllll}\text { Myositis } & \ldots & \ldots & 10 & \mathbf{7 2 6}\end{array}$

$\mathbf{N}$

Nasal catarrh

N

Nasal polypus... $\ldots$

N.O.S. ‥ $\quad \cdots 4470$

$\begin{array}{lllll}\text { Nephritis } & \ldots & \ldots & 8 & 593\end{array}$

$\begin{array}{llll}\text { Nerves . } & 2 & \mathbf{7 9 0} \\ \text { Nervous breakdown } & \cdots & 2 & 318\end{array}$

Nervous debility or ex-

$\begin{array}{lllll}\text { haustion } \quad . . & \ldots & 2 & 318\end{array}$

Nervous dyspepsia $\quad \ldots \quad$ 2 316

$\begin{array}{lllll}\text { Nettlerash } & \ldots & \ldots & 9 & \mathbf{2 4 3}\end{array}$

$\begin{array}{lllll}\text { Neurasthenia } & \ldots & \ldots & \mathbf{2} & \mathbf{3 1 8} \\ \text { Neuritis } & \ldots & \ldots & \mathbf{3} & \mathbf{3 6 6}\end{array}$

$\begin{array}{lllll}\text { Neuritis } & \ldots & \ldots & 3 & \mathbf{3 6 6} \\ \text { Neurosis } & \ldots & \ldots & \mathbf{2} & \mathbf{3 1 8}\end{array}$

$\begin{array}{lllll}\text { Oedema } & . . & \ldots & 1 & \mathbf{7 8 2} \\ \text { Onychia } & & & \end{array}$

$\mathbf{O}$ $\begin{array}{lllll}\text { Onychia } & \ldots & \ldots & 9 & 691 \\ \text { Orchitis } & \ldots & \ldots & 8 & 614\end{array}$ $\begin{array}{lllrr}\text { Orchitis } & . & \ldots & 8 & \mathbf{6 1 4} \\ \text { Osteo-arthritis . . } & \ldots & 10 & \mathbf{7 2 3}\end{array}$ Otitis media or otor-

rhoea

\section{$\mathbf{P}$}

Paronychia

Peptic ulcer $:$.

\begin{tabular}{lllll} 
Pharyngitis & $\ldots$ & $\ldots$ & $\mathbf{4}$ & $\mathbf{4 7 2}$ \\
\hline
\end{tabular}

$\begin{array}{lllll}\text { Pes planus } & \ldots & \ldots & 10 & 746\end{array}$

$\begin{array}{lllll}\text { Phlebitis } & \text {. } & \ldots & 1 & 463 \\ \end{array}$

Phthisis

$\begin{array}{llll}\text { Pleural effusion } & \cdots & 5 & 002 \\ & & 5 & 519\end{array}$

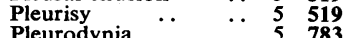

$\begin{array}{lllll}\text { Pleurodynia } & \ldots & \ldots & 5 & \mathbf{7 8 3} \\ & & & & \end{array}$

$\begin{array}{lllll}\text { Pneumonia } & \text {. } & \cdots & 5 & 493 \\ \text { Pneumonitis } & \cdots & & 5 & 492\end{array}$

Pregnancy, condition

$\begin{array}{ccccc}\text { in .. } & \ldots & . & 8 & 649 \\ \text { Pruritus } & \ldots & . . & 9 & 708\end{array}$

$\begin{array}{lllll}\text { Pruritus } & \ldots & \ldots & \mathbf{9} & \mathbf{7 0 8} \\ \text { Psoriasis } & \ldots & \ldots & \mathbf{9} & \mathbf{7 0 6}\end{array}$

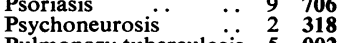

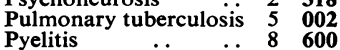

$\begin{array}{llll}\text { Pyelonephritis } & \text {. } & 8 & 600\end{array}$ $\begin{array}{llll}\text { Pyorrhea } & \ldots & 6 & \mathbf{5 3 2} \\ \text { Pyrexial catarrh } & \ldots & 4 & \mathbf{4 7 0}\end{array}$

$\mathbf{Q}$

Quinsy

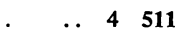

\section{$\mathbf{R}$}

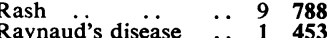

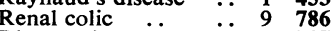
$\begin{array}{lllrl}\text { Renal colic } & \ldots & \ldots & 9 & \mathbf{7 8 6} \\ \text { Rheumatism } & \ldots & \text {. } & 10 & \mathbf{7 2 7}\end{array}$ Rheumatoid, any con-

Rheumatoid, any con- $10 \mathbf{7 2 2}$

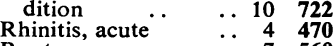
$\begin{array}{lllll}\text { Rupture } & . & \ldots & \mathbf{4} & \mathbf{4 7 0} \\ \end{array}$

\section{$\mathbf{S}$}

$\begin{array}{lllll}\text { Sciatica } & \ldots & \ldots & 3 & 363\end{array}$

$\begin{array}{lllll}\text { Seborrhea } & \ldots & \ldots & 9 & \mathbf{7 0 0}\end{array}$

Septic finger, toe $\quad \ldots .9961$.

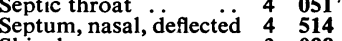

$\begin{array}{lllll}\text { Shingles } & \ldots & \ldots & \mathbf{3} & \mathbf{0 8 8}\end{array}$

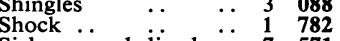

Sickness and diarrhoea 757

$\begin{array}{llll}\text { Sinusitis, acute } & \ldots & \mathbf{4} & \mathbf{4 7 1} \\ \text { Sore throat } & & \mathbf{4} & \mathbf{4 7 2}\end{array}$

$\begin{array}{lllrr}\text { Sore throat } & \ldots & \ldots & \mathbf{4} & \mathbf{4 7 2} \\ \text { Spondylitis } & \ldots & \ldots & 10 & \mathbf{7 2 3}\end{array}$

Sprain or strain :

ankle, foot ... 11845

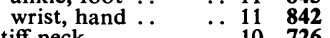

$\begin{array}{lllll}\text { Stiff neck } & \ldots & \ldots & 10 & \mathbf{7 2 6}\end{array}$

$\begin{array}{llll}\text { Stomach ulcer. . } & \ldots & \mathbf{6} & \mathbf{5 4 0} \\ \text { Stomatitis } & & \mathbf{5 3 6}\end{array}$

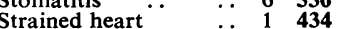

$\begin{array}{lllll}\text { Stye } & \ldots & \ldots & \mathbf{3} & \mathbf{3 7 2}\end{array}$

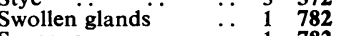

$\begin{array}{lllll}\text { Syncope } & \ldots & \ldots & 1 & \mathbf{7 8 2} \\ \text { Synovial effusion } & \ldots & 10 & \mathbf{7 3 8}\end{array}$

$\begin{array}{lllll}\text { Synovial effusion } & \ldots & 10 & 738 \\ \text { Synovitis } & \ldots & \ldots & 10 & \mathbf{7 4 1}\end{array}$

\section{$\mathbf{T}$}

$\begin{array}{lllrr}\text { Tachycardia } & \ldots & \ldots & 1 & \mathbf{7 8 2}\end{array}$

$\begin{array}{lllrr}\text { Tenosynovitis } & . . & \ldots & 10 & \mathbf{7 4 1} \\ \text { Tinea pedis } & \ldots & \ldots & 9 & \mathbf{1 3 1}\end{array}$

\begin{tabular}{lllll} 
Toothache & $\ldots$ & $\ldots$ & 6 & $\mathbf{5 3 4}$ \\
\hline
\end{tabular}

Tonsillitis, acute $\quad \ldots \quad 44773$

$\begin{array}{llll}\text { Thrombosis .. } & \ldots & 1 & \mathbf{4 6 6} \\ \text { Tracheitis, acute } & \ldots & 4 & \mathbf{4 7 4}\end{array}$

$\begin{array}{llll}\text { Tracheitis, acute } \ldots & 4 & 474 \\ \text { Tuberculosis, pulmon- }\end{array}$

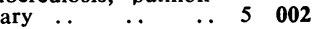

\section{$\mathbf{U}$}

Ulcer of skin .. $\quad \ldots \quad 9 \quad 715$

Ulcer of duodenum $\ldots 6 \quad 6 \quad 541$

$\begin{array}{llll}\text { Ulcer of stomach } & \ldots & \mathbf{6} & \mathbf{5 4 0} \\ \text { Urinary infection } & & \mathbf{8} & \mathbf{6 0 0}\end{array}$

$\begin{array}{lllll}\text { Urinary infection } & \ldots & 8 & \mathbf{6 0 0} \\ \text { Urticaria } & . . & \ldots & 9 & \mathbf{2 4 3}\end{array}$

\section{V}

Varicose ulcer of veins $14 \mathbf{4 6 0}$

$\begin{array}{lllll}\text { Verruca } & \ldots & \ldots & 9 & 696\end{array}$

$\begin{array}{lllll}\text { Vertigo; } & \ldots & \ldots & 3 & 780\end{array}$

$\begin{array}{ccccc}\begin{array}{c}\text { Vincent's angina (or } \\ \text { infection) }\end{array} & \ldots & \ldots & 4 & 070\end{array}$

$\begin{array}{ccccc}\text { infection) } & \ldots & \ldots & \mathbf{4} & \mathbf{0 7 0} \\ \text { Vomiting } & \ldots & \ldots & \mathbf{6} & \mathbf{7 8 4}\end{array}$

$\begin{array}{lllll} & \text { W } & & & \\ \text { Warts } \ldots & \ldots & \ldots & 9 & \mathbf{6 9 6} \\ \text { Wen } \ldots & \ldots & \ldots & 9 & 714 \\ \text { Whitlow } & \ldots & \ldots & 9 & \mathbf{6 9 1}\end{array}$

Code all other diseases as Group 12 (Miscellaneous) 